\title{
IN HALTSVERZEICHN IS
}

NATUR

Tageszeiten ................... 7

Jahreszeiten . . . . . . . . . . . . 11

Naturbilder . . . . . . . . . . . . . 25

LAND UND VOLK . . . . . . . . . . 37

LANDSCHAFTEN UND STÄTTEN

Attika. . . . . . . . . . . . . . 45

Rhetorischer Preis des Landes . . . . . . . . . . . 45

Dichterische Verklärung in klassischer Zeit . . . . . . 49

Land und Volk . . . . . . . . . . . . . . . . 55

Athen ................ 61

Dichterische Verklärung . . . . . . . . . . 61

Klassische Würdigung. . . . . . . . . . . 63

Römische Stimmen . . . . . . . . . . . . . 73

Am Ende des antiken Zeitalters. . . . . . . . . . . . 75

Stadtbeschreibung im einzelnen . . . . . . . . . 77

Attische Stätten . . . . . . . . . . . . . . . . . . . . 89

Im Saronischen Golf . . . . . . . . . . . . 103

Megaris und Isthmos . . . . . . . . . . . . . 107

Korinth . . . . . . . . . . . . . . . . 111

Argolis . . . . . . . . . . . . . . 117

Sparta. . . . . . . . . . . . . . . . 127

Messenien . . . . . . . . . . . . . . . 135

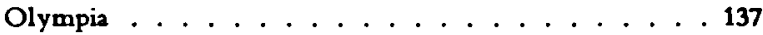

Dichterische Verklärung . . . . . . . . . . . 137

Würdigung und Beschreibung. . . . . . . . . . . . . 139

Arkadien .................. 151

Böotien . . . . . . . . . . . . . . . 159

Land und Volk . . . . . . . . . . . . . . . . . . 159

Theben ................ . 163

Böotische Stätten . . . . . . . . . . . . . . . 167

Delphi .................. . 173

Dichterische Verklärung . . . . . . . . . . . . 175

Würdigung und Beschreibung . . . . . . . . 177

Thermopylen ................... 189

Eubö̀ . . . . . . . . . . . . . . . 193

Delos . . . . . . . . . . . . . . . . . . 199

Dichterische Verklärung . . . . . . . . . . . . . 199

Würdigung und Beschreibung . . . . . . . . . . 205

Kykladen . . . . . . . . . . . . . . . 209

Lesbos, Chios, S2mos . . . . . . . . . . . . . 215 
Dodekrnes, Zypern . . . . . . . . . . . . . . . 225

Kret2 . . . . . . . . . . . . . . . . . 239 Ionische Inseln . . . . . . . . . . . . . . . . . . 245 Epirus. . . . . . . . . . . . . . . 253 Thessalien . . . . . . . . . . . . . 255 Makedonien und Thrakien . . . . . . . . . . 265 Der Athos . . . . . . . . . . . . . . . 265

ROMISCHE HULDIGUNG . . . . . . . . . . . . . 273

Nachwort . . . . . . . . . . . . . . 276

Orts- und Sachregister. . . . . . . . . . . . 279 Nachweis der Ubersetzungen ......... 284 